\title{
The Role of Nitric Oxide in Regulating Intestinal Redox Status and Intestinal Epithelial Cell Functionality
}

\author{
Kaiwen Mu, Shengwu Yu and David D. Kitts * \\ Faculty of Land and Food Systems, The University of British Columbia, Vancouver, BC V6T 1Z4, Canada; \\ muk@mail.ubc.ca (K.M.); tedyubca@gmail.com (S.Y.) \\ * Correspondence: david.kitts@ubc.ca; Tel.: +1-604-822-5560
}

Received: 12 March 2019; Accepted: 3 April 2019; Published: 9 April 2019

\begin{abstract}
Important functions of intestinal epithelial cells (IECs) include enabling nutrient absorption to occur passively and acting as a defense barrier against potential xenobiotic components and pathogens. A compromise to IEC function can result in the translocation of bacteria, toxins, and allergens that lead to the onset of disease. Thus, the maintenance and optimal function of IECs are critically important to ensure health. Endogenous biosynthesis of nitric oxide (NO) regulates IEC functionality both directly, through free radical activity, and indirectly through cell signaling mechanisms that impact tight junction protein expression. In this paper, we review the current knowledge on factors that regulate inducible nitric oxide synthase (iNOS) and the subsequent roles that NO has on maintaining IECs' intestinal epithelial barrier structure, functions, and associated mechanisms of action. We also summarize important findings on the effects of bioactive dietary food components that interact with $\mathrm{NO}$ production and affect downstream intestinal epithelium integrity.
\end{abstract}

Keywords: intestinal epithelial cells; nitric oxide signaling; free radicals

\section{Introduction}

Intestinal epithelial cells (IECs) exist as a continuous layer of cells that line the surface of the intestinal epithelium and display important roles in the digestion of food and the absorption of nutrients. IECs are tightly bound by intercellular junctional complexes which allow the epithelium to form a barrier that separates the luminal side from the serosal side of the cell. Specific tight junction protein mutations or aberrant signaling that disrupt the tight junction structure reduce functionality, as evidenced by the microbial invasion of interstitial tissues [1].

Nitric oxide (NO) has multiple properties that regulate IEC function. Three endogenous isoforms of NO synthase (NOS), neuronal NOS (NOS1), inducible NOS (iNOS; NOS2), and endothelial NOS (NOS3) are responsible for $\mathrm{NO}$ production in intestinal epithelial cells. All biosynthesis pathways use L-arginine and molecular oxygen through a complex oxygen-dependent reaction that involves electron transfer and leads to the equimolar production of $\mathrm{NO}$ and L-citrulline. Several co-factors, including nicotinamide adenine dinucleotide phosphate (NADPH) and tetrahydrobiopterin (BH4), are also required [2-4]. Nitric oxide synthase production is regulated by transcriptional and post-transcriptional mediators and cell signaling pathways.

NO has a dual role in IEC tight junction regulation. On the one hand, NO inhibits lipid and protein oxidation by directly scavenging cellular lipid or protein radicals that are formed during lipid peroxidation and protein oxidation reactions. In addition, $\mathrm{NO}$ has a protective role against intestinal barrier dysfunction, brought on by oxidative stress that includes hydrogen peroxide-induced changes in the protein tyrosine phosphorylation of IECs [5]. Pre-treatment of Caco-2 cells with NO 
has been shown to prevent a reduction in the transepithelial electrical resistance induced by $\mathrm{H}_{2} \mathrm{O}_{2}$ in a dose-dependent manner [5]. Tight junction proteins are closely regulated by cellular redox homeostasis. NO modulates the intestinal epithelial cell tight junction by altering the glutathione (GSH)/GSSG balance that results in the inactivation of phosphatases and protein tyrosine phosphorylation. NO also triggers a redox imbalance through a free radical mechanism that initiates lipid and protein oxidation reactions. Intracellular pathways of cell signaling are sensitive to redox changes via the modification of enzymes altered by NO. Some examples of this include the oxidation of glutathione, the inactivation of protein phosphatases directly reacting with protein and lipid radicals, and sequestering metal cofactors which deactivate enzymes. The process of S-nitrosylation or nitration of redox-sensitive proteins also alters cell signaling [6,7]. A balanced redox status is therefore paramount for the maintenance of protein structure, such as those that comprise tight junctions that enable intestinal cell functionality.

\section{Regulation of Nitric Oxide Synthase Expression}

A moderate amount of NO is continuously produced by NOS1 and NOS3, both of which are constitutively expressed in intestinal epithelial cells [8]. Most resting cells do not express iNOS, which is the primary isoform of NOS in intestinal cells, but could be induced by cytokines and some microbial products. The expression of iNOS can be constitutive or induced in vivo, for example by cytokines [9-12] during large intestinal inflammation or triggered by bacterial infections [13-16]. In IECs that are polarized, stable end-products of $\mathrm{NO}$, such as nitrite and nitrate, are primarily found on the apical side. This suggests that both NO production and its reaction with metabolites are located on the apical side of intestinal epithelial cells [13]. iNOS-generated NO exerts immunomodulatory and antitumor effects through complex mechanisms in addition to possessing a number of microbial, antiviral, and anti-parasitic effects. Nonetheless, the uncontrolled induction and activation of iNOS expression is related to the pathophysiology of human diseases; therefore, iNOS expression has to be highly regulated in order to ensure overall physiological wellbeing.

The transcription of iNOS is the major regulatory scheme for NO production. Molecular iNOS transcription mechanism studies previously performed in distinct cells have indicated that different signaling pathways are triggered depending on cell types and inducers [17-22]. These in turn activate transcription factors, such as protein kinase C [23], tyrosine kinase [24], mitogen-activated protein kinases (MAP kinase) [25], and inhibitors such as protein tyrosine phosphatases [26], phosphoinositide-3-kinase [27], and nuclear factor kappa B (NF-kB) [28-31].

Recent evidence suggests that iNOS mRNA stability is highly associated with the expression of iNOS. When cells are not stimulated, even though iNOS mRNA is constitutively transcribed at basal levels, neither iNOS mRNA nor the expression of the iNOS protein can be found. These findings suggest that iNOS mRNA is probably highly unstable in non-induced cells [32-34]. There are a number of proteins that regulate the stability of iNOS mRNA. These proteins include protein kinase $\mathrm{C} \delta$ (PKC) $[35,36]$ and c-Jun $\mathrm{N}$-terminal kinase (JNK) [37-39]. In addition, other factors that regulate iNOS mRNA stability include transforming growth factor- $\beta$ (TGF- $\beta$ ) [40,41], dexamethasone [42-44], 8-bromo-cyclic guanosine monophosphate (cGMP) [45,46], intracellular calcium elevating agents [47], forskolin (activates adenylate cyclase), dibutyryl cyclic adenosine monophosphate (cAMP) (membrane permeable cAMP analog) [48,49], tetrahydrobiopterin (BH4) [50,51], and L-arginine [52,53].

The expression of iNOS is regulated by multiple signaling pathways that involve either activation [48] or inhibition [54] by cAMP-activating compounds. Conflicting evidence exists for the role of PKC and its related cytokine induction of iNOS expression, whereas both positive and negative results have been obtained with the use of PKC-activating phorbol esters or PKC inhibitors [23,55]. This may be due to the difference in the functionality of PKC in different isoforms, as discussed in several studies. Even though the level of activity of iNOS is independent of $\left[\mathrm{Ca}^{2+}\right]_{\mathrm{i}}$, this can also affect iNOS transcription [8,56,57]. Many studies have shown the effect of MAP kinase on iNOS expression [25,58-61]. 
In addition to transcriptional and post-transcriptional regulations, NO production can be modulated by a wide range of dietary components against various kinds of inducers that include oxysterols, lipopolysaccharide (LPS), tumor necrosis factor alpha (TNF- $\alpha$ ), interleukin-1 $\beta$ (IL-1 $\beta$ ), and a combination of interferon gamma (IFN- $\gamma$ ) and phorbol 12-myristate 13-acetate (PMA). Examples of some dietary components with this bioactivity include a number of polyphenolic compounds naturally present in fruits and vegetables [62-66], bioactive peptides derived from milk proteins [67], amino acids [68], or products of the Maillard reaction [69] (Table 1). Ingested nitrate is taken up in salivary glands which secrete it for further transformation by facultative anaerobic bacteria to nitrite-an important example of biological symbiosis where humans do not possess the required nitrate reductases. Nitrite is further reduced to $\mathrm{NO}$ as a result of low stomach $\mathrm{pH}$, which represents another source of inorganic nitrate; this is particularly important as it represents a source of NO for the regulation of gastric mucosal blood flow.

Table 1. Effect of dietary component on nitric oxide production in intestinal epithelial cells.

\begin{tabular}{|c|c|c|c|c|}
\hline Dietary Component & Inducer & Cell Type & Description & Ref. \\
\hline Olive oil polyphenols & Oxysterols & Caco- 2 cells & $\begin{array}{l}\text { Oxysterols induced nitric oxide (NO) } \\
\text { generation was suppressed by } \\
\text { tested compounds }\end{array}$ & [70] \\
\hline $\begin{array}{l}\text { Hydroxytyrosol } \\
\text { and tyrosol metabolites }\end{array}$ & Lipopolysaccharide (LPS) & Caco- 2 cells & $\begin{array}{l}\text { LPS-induced NO release was } \\
\text { inhibited by tested compounds }\end{array}$ & [71] \\
\hline Cinnamon & LPS & $\begin{array}{l}\text { Caco- } 2 \text { and Raw } \\
264.7 \text { co-culture }\end{array}$ & $\begin{array}{l}\text { LPS-induced NO release was } \\
\text { inhibited by tested compound }\end{array}$ & [72] \\
\hline $\begin{array}{l}\text { Gastrointestinal-digested } \\
\text { blackcurrant extracts }\end{array}$ & LPS & $\begin{array}{l}\text { Caco- } 2 \text { and Raw } \\
264.7 \text { co-culture }\end{array}$ & $\begin{array}{l}\text { LPS-induced NO release was } \\
\text { inhibited by tested compounds }\end{array}$ & [63] \\
\hline Purple carrot anthocyanins & LPS & $\begin{array}{l}\text { Caco- } 2 \text { and Raw } \\
264.7 \text { co-culture }\end{array}$ & $\begin{array}{l}\text { LPS-induced NO release was } \\
\text { inhibited by tested compounds }\end{array}$ & [64] \\
\hline $\begin{array}{l}\text { Bovine and soybean milk } \\
\text { bioactive compounds }\end{array}$ & LPS & Caco- 2 cells & $\begin{array}{l}\text { LPS-induced NO release was } \\
\text { inhibited by tested compounds }\end{array}$ & [67] \\
\hline Resveratrol & LPS & $\begin{array}{l}\text { Caco- } 2 \text { cells } \\
\text { or SW } 480\end{array}$ & $\begin{array}{l}\text { LPS-induced NO release was } \\
\text { inhibited by tested compound }\end{array}$ & [65] \\
\hline Lutein & Tumor necrosis factor (TNF)- $\alpha$ & Caco- 2 cells & $\begin{array}{l}\text { TNF- } \alpha \text { was suppressed by } \\
\text { tested compound }\end{array}$ & [66] \\
\hline L-arginine & Interleukin (IL)-1 $\beta$ & Caco- 2 cells & $\begin{array}{l}\text { IL- } 1 \beta \text {-induced NO release was } \\
\text { inhibited by tested compound }\end{array}$ & [68] \\
\hline Maillard reaction products & $\begin{array}{c}\text { IFN- } \gamma+\text { phorbol 12-myristate } \\
\text { 13-acetate (PMA) }\end{array}$ & Caco-2 cells & $\begin{array}{l}\text { Induced NO release was inhibited by } \\
\text { tested compounds }\end{array}$ & [69] \\
\hline
\end{tabular}

\section{NO Regulation of Intestinal Tight Junction Function}

IECs are vital components for the paracellular absorption of nutrients [73]. In recent years, a number of tight junction proteins have been discovered, and some have been shown to function as scaffolds that link integral proteins with the actin cytoskeleton (Figure 1) [73]. Some tight junction proteins function to cross-link transmembrane junction proteins [73], while some are involved in cell signaling through an association with kinases and Ras. There are some sub-membranous junctional proteins which also contribute to gene expression because of specific binding properties to transcription factors. Occludin and claudin proteins, for example, are common integral proteins that constitute the backbone of tight junction strands. Some studies have emphasized the role of iNOS in tight junction disruption. NO, for example, can be an important mediator in the regulation of intestinal permeability [74]. However, the over-production of NO synthesized by iNOS can be attributed to intestinal barrier dysfunction [9]. A low level of NO synthesized by constitutional nitric oxide synthase appears to be a homeostatic control to optimize its function. On the other hand, similar to the intracellular synthesis of NO by iNOS, it is noteworthy that NO is also produced extracellularly by a NO donor, such as sodium nitroprusside or S-nitroso-N-acetylpenicillamine (SNAP); both of which have a detrimental effect on tight junction function [9]. Tang et al. [75] used in vitro monolayer cell-based and in vivo mouse studies to show that alcohol induced the dysregulation of intestinal tight 
junction proteins, such as zonula occludens- 1 (ZO-1). This was ascribed to the upregulation of intestinal iNOS by alcohol. In other words, iNOS signaling has an indispensable role in alcohol-induced ZO-1 disruption [75]. Studies performed by Han and others support that NO plays a role in compromised epithelial barrier function. They showed that cytokines decrease epithelial barrier function by decreasing the expression of $\mathrm{ZO}-1, \mathrm{ZO}-3$, and occludin protein; moreover, these effects could be modulated by the NO scavenger 2-(4-carboxyphenyl)-4,4,5,5-tetramethylimidazoline-1-oxyl-3-oxide (cPTIO) [74]. On the other hand, NO may protect tight junctions against reactive oxygen species-induced dysfunction. Studies have shown that hydrogen peroxide-induced tight junction protein phosphorylation and further barrier disruption was mitigated by adding a NO donor [5].

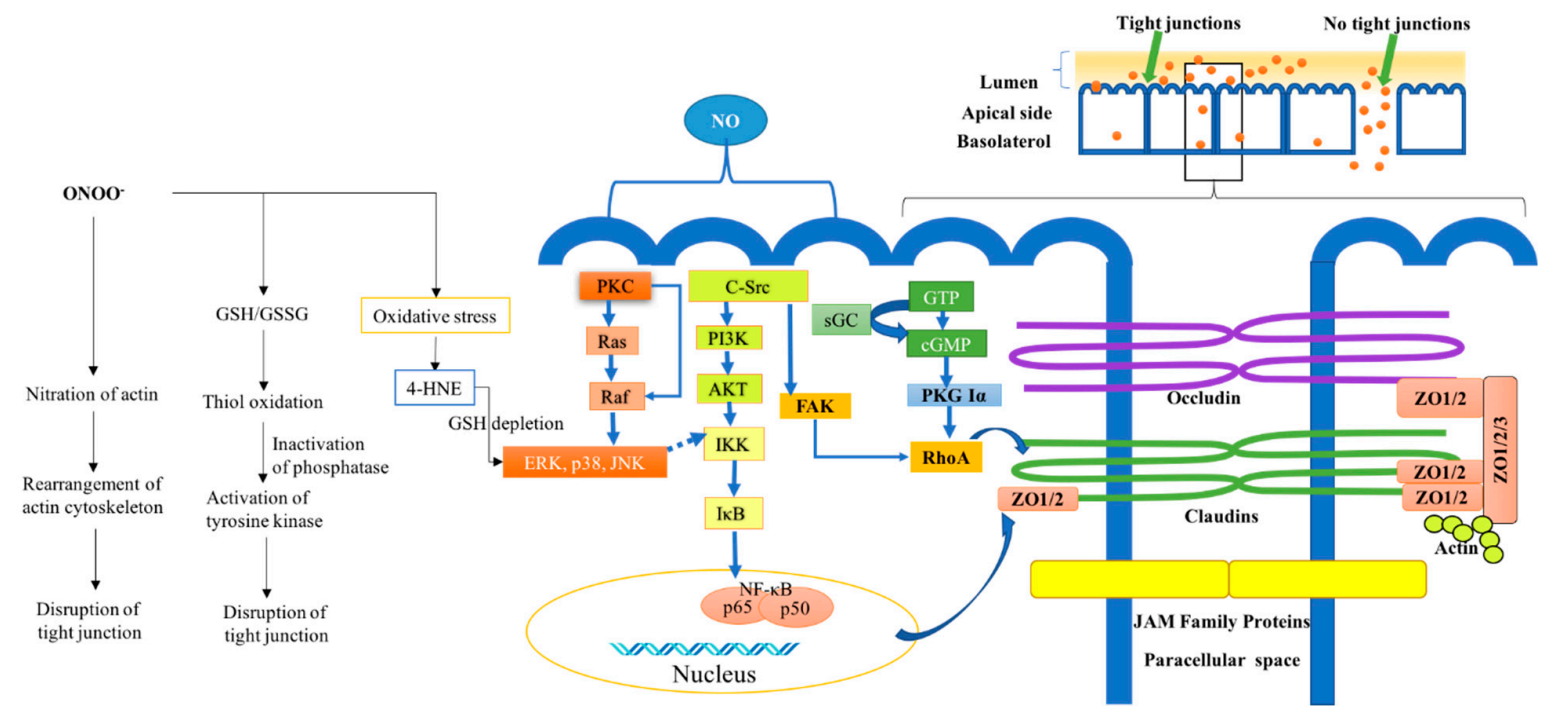

Figure 1. Involvement of NO in cellular signaling activity.

\section{Effect of Nitric Oxide on Intestinal Epithelial Tight Junctions: Mechanism of Action}

\subsection{The Involvement of Nitric Oxide in Cellular Signaling Activity}

In general terms, the known mechanism of action of $\mathrm{NO}$ on redox balance includes a direct effect, where NO directly reacts with target molecules, i.e., metal centers and lipid radicals. Alternatively, $\mathrm{NO}$ has an indirect effect on redox, where it first reacts with reactive oxygen species (ROS), such as $\mathrm{O}_{2}$ or $\mathrm{O}_{2}{ }^{\bullet-}$ to form $\mathrm{ONOO}^{-}$or $\mathrm{ONOOH}[76,77]$, prior to reacting with the target molecule. The mechanism behind nitric oxide overproduction-induced abnormal intestinal barrier function includes the effect of $\mathrm{NO}$ on redox balance and on cell signaling, which further influences tight junction function [78,79].

\subsubsection{Binding to Metal Centers}

A major target of NO-regulated cell signaling is soluble guanylycylase (sGC), a heme-containing enzyme that converts GTP to cGMP, an important signaling molecule. NO activates sGC by binding to its heme group, leading to changes in the porphyrin ring structure. sGC is activated in the presence of low NO concentrations (10-100 nM), and the activation of sGC leads to a significant increase in the rate of cGMP synthesis, which in turn activates protein kinase (PKG) upon the binding of cGMP [80]. Cyclic guanosine monophosphate-dependent PKG I $\alpha$ binds directly to and also regulates a Ras homolog gene family, member A (RhoA) [81]. RhoA is a small G-protein in the Rho family. Studies have shown that it can regulate tight junction protein expression by modulating Claudin-2 expression [82] and actin [83,84], as shown in Figure 1. 


\subsubsection{S-Nitrosylation on Redox Sensitive Cysteines of Susceptible Proteins}

NO reacts directly with thiol-containing amino acids and induces the formation of S-nitroso-thiols from cysteine residues (termed S-nitrosylation). The reaction results in the altered function or deactivation of enzymes [8,85]. MAPK signaling has an important role in cellular activities including regulating tight junction protein expression [86]. Three well-characterized MAPK families identified are extracellular signal-regulated kinase (ERK), Jun kinase (JNK/SAPK), and p38 MAPK. NO is implicated in MAPK signaling by nitrosylating cysteine-118 in p21 Ras, a kinase involved in the MAP kinase cascade activation [87]. Another example is the S-nitrosylation of c-Src, which further activates the NF- $\mathrm{kB}$ pathway. The activation of c-Src also affects RhoA by activating focal adhesion kinase (FAK). S-nitrosylation may also occur with the NF-kB subunit p50 (residue Cys 62). These signaling activities involving a redox-sensitive nuclear transcription factor (NF- $\mathrm{kB}$ ) are critical for the regulation of tight junction proteins [88-93]. In quiescent conditions, NF- $\kappa B$ is bound to a family of inhibitory proteins known as NF- $\mathrm{kB}$ inhibitors (I- $\mathrm{kBs}$ ), and the complexes are retained in the cytoplasm [94]. The phosphorylation of I- $\mathrm{kB}$ by the the I- $\mathrm{kB}$ kinase (IKK) complex activates the NF- $\mathrm{kB}$, causing I- $\mathrm{kB}$ degradation by the ubiquitin-proteasome pathway (UPP). The released NF- $\mathrm{kB}$ translocates to the nucleus and binds to promoters on target genes, thereby regulating tight junction protein expression [88]. In addition, there is feedback on NF- $\mathrm{KB}$, a known mediator of iNOS expression which in turn regulates NO production. Studies have shown that NO also affects NF- $\mathrm{KB}$ activity by inhibiting the DNA binding of recombinant NF- $\mathrm{KB}$ p50 and p65 homodimers as well as p50/p65 heterodimers [95]. The inhibition of p50 DNA binding by NO production can lead to modification of the conserved redox-sensitive C62 residue [95].

Signaling pathways are sensitive to the redox environment; hence, $\mathrm{NO}$ affects signaling pathways due to its involvement in pathways that alter redox status. For example, the Keap1/Nrf2-ARE pathway has an important role in protecting cells from oxidative stress [96]. Under normal conditions, the transcription factor Nrf2 is bound to the actin-anchored protein Keap1, and this interaction retains the Nrf2 in the cytoplasm while maintaining a low basal expression of Nrf2-regulated genes [96]. Human Keap1 has 27 cysteine residues, and several are known to be primary sensors for stress signals. Hence, modification on these critical cysteine residues produces conformational changes in Keap1, which liberates Nrf2 from Keap1. After being released from Keap1, Nrf2 translocates to the nucleus and transactivates the expression of cytoprotective genes, thereby enhancing cell survival. NO may contribute to the nuclear accumulation of Nrf2 by S-nitrosylation of Keap1, thus facilitating its dissociation from Keap1 [96]. The activation of Nrf2 upregulates antioxidant response enzymes that lead to the maintenance of optimum intracellular glutathione levels to ensure a redox balance is obtained for peak tight junction protein functionality.

\subsubsection{Reactions of NO with Proteins that Affect Cell Signaling}

Peroxynitrite leads to protein nitration. Protein tyrosine nitration refers to a covalent protein modification process that occurs from the addition of a nitro $\left(-\mathrm{NO}_{2}\right)$ group onto the ortho carbons on the aromatic ring of tyrosine residues, catalyzed primarily by metalloproteins [6]. Nitrogen dioxide has been found to be capable of nitrating tyrosine residues [97-99].

$\mathrm{NO}$ also reacts with thiol groups as evidenced by the relevant example involving the glutathione (GSH/GSSG) redox system, a critical balance for cell survival. Changes in the GSH/GSSG ratio buffer reflect changes in intracellular redox alterations [100]. Under physiological conditions, the reduced form of glutathione is 10- to 100-fold higher than its oxidized form. Studies have shown that changes in this ratio may modulate several cellular reactions involved in signal transduction [101,102]. When cells are subjected to oxidative stimuli, the GSH/GSSG ratio tends to decrease, by either increasing the amount of oxidized glutathione or decreasing the amount of reduced glutathione. The oxidation of the thiol group of glutathione leads to the inactivation of phosphatases, which further activates tyrosine kinases. The activation of tyrosine kinase leads to the disruption of the tight junction protein [103]. 
NO has a critical role in modulating glutathione homeostasis; by oxidizing GSH and generating GSNO, transnitrosylation reactions are mediated [104]. In addition, the $\mathrm{ONOO}^{-}$produced from $\mathrm{NO}$ reacting with $\mathrm{O}_{2}{ }^{\bullet-}$ interact with reduced glutathione and lead to the reversible S-glutathionylation of proteins [104].

In summary, NO has been shown to mediate post-translational modifications of proteins, representing a mechanism for cell signaling. The major four modification pathways are: (i) binding to metal centers, (ii) NO-induced formation of S-nitrosylation on redox-sensitive cysteines of susceptible proteins, (iii) nitration of amino acids including tyrosine and tryptophan, and (iv) oxidation of thiols, including cysteine and methionine residues and tyrosine [6,7]. Some examples of the effect of NO on cell signaling are discussed herein. In addition, NO can interrupt protein oxidation via inhibiting the formation of radicals produced in lipid and protein oxidation reactions.

\subsection{Effect of NO on Protein Oxidation and Interference with Lipid and Protein Oxidation Reactions}

The oxidation of membrane lipids occurs with unsaturated fatty acids that are susceptible to both enzymatic and non-enzymatic oxidation mechanisms (Figure 2). Enzymatic reactions of lipids proceed in the presence of lipoxygenases (LOX), a family of iron-containing enzymes that transform polyunsaturated fatty acids (PUFA) to lipid hydroperoxides (LOOH) [105]. The non-enzymatic oxidation of lipids is initiated by a free radical chain reaction that results in the formation of peroxyl radicals [106,107], which in turn oxidizes other molecules, thereby inducing a chain reaction. Figure 2 shows the sequence of reactions involved in the lipid oxidation scheme.

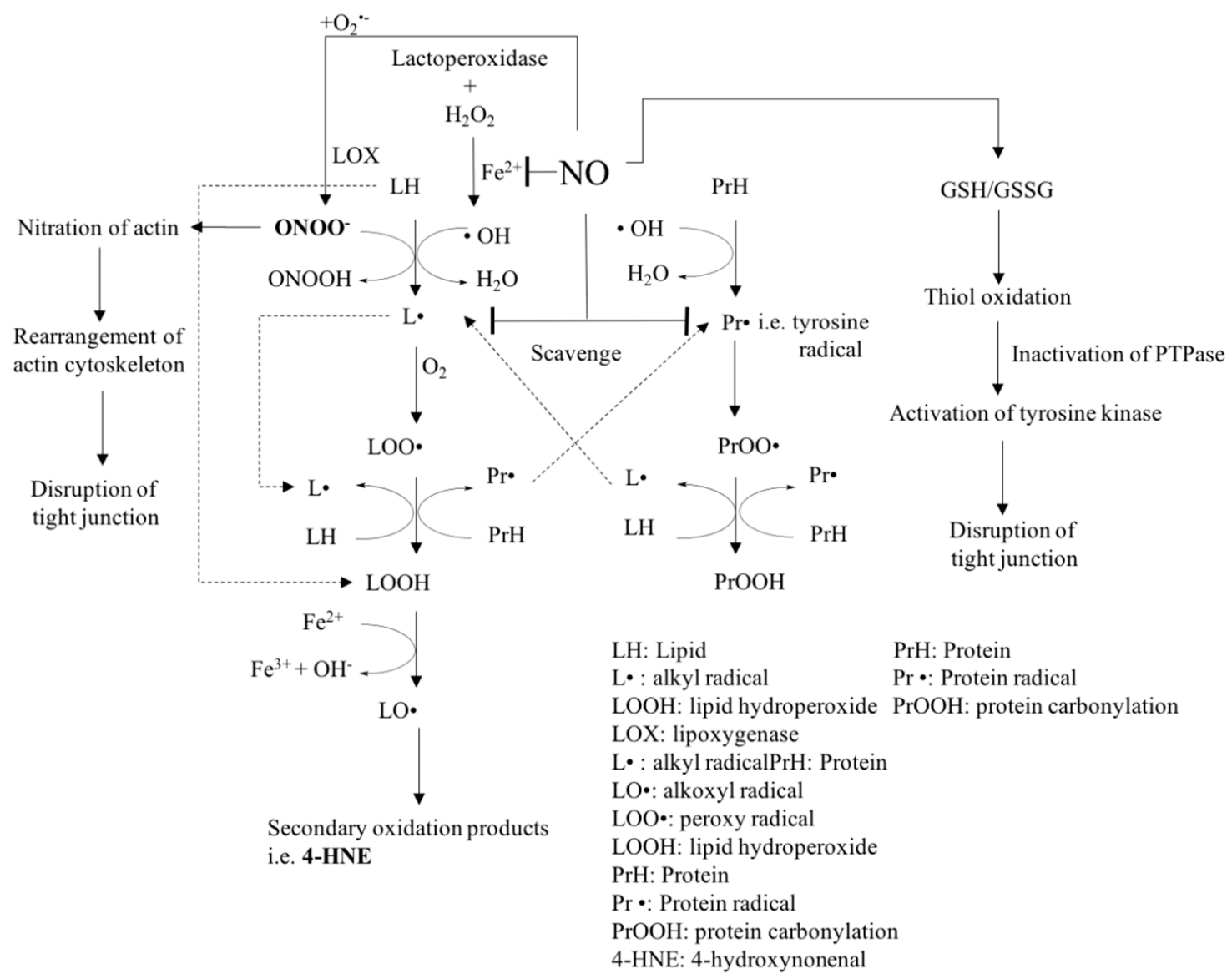

Figure 2. Examples of mechanisms that are involved with nitric oxide on epithelial barrier disruption by modulating the redox homeostasis of cells [103].

Free radical chain reactions are initiated and form hydroxyl radicals; the formation of hydroxyl radicals is accelerated when in the presence of transition metal compounds, such as iron [108]. 
This leads to the abstraction of hydrogen from an unsaturated fatty acid to produce a fatty acid radical termed alkyl radical $(\mathrm{L} \cdot)$. Thereafter, the addition of oxygen to the $\mathrm{L} \cdot$ contributes to the formation of a peroxyl radical (LOO.). Due to its high energy level, the abstraction of another hydrogen from the unsaturated lipid occurs, which leads to the formation of a lipid hydroperoxide (LOOH) and a new $\mathrm{L} \cdot$ on another unsaturated fatty acid molecule. Lipid hydroperoxides are referred to as primary oxidation products, which are further reacted in a Fenton reaction that yields alkoxyl radicals (LO·). $\beta$-scission reactions occur which yield secondary lipid oxidation products, such as aldehyde malonaldehyde [106,108]. Similar to lipid oxidation, protein oxidation pathways follow parallel free radical chain reactions [109-111]. Lipid hydroperoxides can lead to the formation of protein-centered radicals [112]. Oxygen can be added to protein-centered radicals with the formation of a protein peroxyl radical (PrOO-), and the high energy of PrOO- abstracts hydrogen from another protein molecule, thereby leading to the formation of protein carbonyls (PrOOH) [111]. In the presence of peroxidizing lipids, proteins form protein-protein cross-linked structures which result in the reduction of protein solubility [112]. The protein-protein cross-linkages proceed via the collision of two protein radicals that result in a termination reaction [113]. In addition to protein-protein cross-linkages, lipid-protein cross-linkages also occur [112]. Protein scission and amino acid damage may also occur [112].

Amino acid side chains are susceptible to free radical attack, depending on the type of amino acid. For example, cysteine is the most susceptible amino acid residue, and it is often preferentially oxidized [114]. In particular, amino acids which have a sulfhydryl amino group, thioether, indole ring, and imidazole rings, respectively, as side groups are relatively more sensitive to oxidation reactions initiated by oxidizing lipids and related products $[112,115]$. Thus, cysteine, methionine, lysine, histidine, arginine, as well as tryptophan residues are common targets of free radicals generated via lipid oxidation [114].

Secondary oxidation products, such as malondialdehyde (MDA) and 4-hydroxynonenal (4 HNE), react with proteins by forming covalent linkages [112] and lead to intra- or inter-molecular cross-linking [116]. These conformational changes that result in the formation of protein adducts lead to the aggregation or precipitation of proteins, thereby affecting normal protein degradation pathways [117]. It is important to point out that lipid peroxidation products such as 4-HNE can also influence tight junction stability by modulating glutathione levels and the MAPK signaling pathway.

NO also acts as an antioxidant to scavenge peroxyl radicals and therefore is involved in inhibiting lipid peroxidation propagation reactions [118-123]. NO is not a strong oxidant per se and therefore is unable to extract bis-allylic hydrogen from PUFA, which is needed to initiate the peroxidation chain reaction [124]. In addition to non-enzymatic lipid oxidation, NO affects enzymatic lipid oxidation by inactivating enzymes, such as cytochrome p450, lipoxygenases, or cyclooxygenases [125], through a reduction of the active site non-heme iron or heme to an inactive ferrous form.

NO also has indirect effects mediated by reactive nitrogen species (RNS) that are produced by the interaction of $\mathrm{NO}$ with superoxide anions, yielding the formation of highly reactive peroxynitrite $\left(\mathrm{ONOO}^{-}\right)$. The highly reactive peroxynitrite $\left(\mathrm{ONOO}^{-}\right)$initiates lipid peroxidation in a radical manner $[124,126-128]$. At the same time, the $\mathrm{RNS}\left(\mathrm{ONOO}^{-}\right)$is less reactive compared to the superoxide radical.

Among these mechanisms of action, the reaction route for $\mathrm{NO}$ within a cell is determined by three main criteria that include the degree of exposure, the availability of target molecules, and the structure of target proteins [129]. Flux rates of NO and its sources determine the degree of NOS exposure to NO. For example, the reaction of $\mathrm{NO}$ with superoxide, molecular oxygen, or thiol groups is dependent on the flux rate of NO relative to the concentration of these target molecules [129].

\section{Conclusions}

NO has multiple effects on intestinal epithelial cell functionality that involve numerous complex intracellular and molecular mechanisms of actions. A balanced redox status is a central and critical factor for the maintenance of pathways important for IEC functionality. Thus, modulating NO 
to maintain cell redox homeostasis is one important underlying mechanism to ensure optimal intestinal tight junction function. This is a prerequisite for a healthy gut despite the potential for frequent exposure to potential toxins (allergens) and pathogens that can be consumed simultaneously or at different times from the diet.

Funding: This research was funded by Natural Sciences and Engineering Research Council of Canada (grant number RGPIN 38349-06, 38349-2011 RGPIN and 38349-2019).

Conflicts of Interest: The authors declare no conflict of interest.

\section{References}

1. Turner, J.R. Intestinal mucosal barrier function in health and disease. Nat. Rev. Immunol. 2009, 9, 799-809. [CrossRef] [PubMed]

2. Knowles, R.G.; Moncada, S. Nitric oxide synthases in mammals. Biochem. J. 1994, 298 Pt 2, 249-258. [CrossRef]

3. Marletta, M.A. Nitric oxide synthase: Aspects concerning structure and catalysis. Cell 1994, 78, 927-930. [CrossRef]

4. Alderton, W.K.; Cooper, C.E.; Knowles, R.G. Nitric oxide synthases: Structure, function and inhibition. Biochem. J. 2001, 357, 593-615. [CrossRef] [PubMed]

5. Katsube, T.; Tsuji, H.; Onoda, M. Nitric oxide attenuates hydrogen peroxide-induced barrier disruption and protein tyrosine phosphorylation in monolayers of intestinal epithelial cell. Biochim. Biophys. Acta 2007, 1773, 794-803. [CrossRef] [PubMed]

6. Gow, A.J.; Farkouh, C.R.; Munson, D.A.; Posencheg, M.A.; Ischiropoulos, H. Biological significance of nitric oxide-mediated protein modifications. Am. J. Physiol. Lung Cell. Mol. Physiol. 2004, 287, L262-L268. [CrossRef] [PubMed]

7. Tegeder, I. Nitric oxide mediated redox regulation of protein homeostasis. Cell. Signal. 2019, 53, 348-356. [CrossRef] [PubMed]

8. Korhonen, R.; Lahti, A.; Kankaanranta, H.; Moilanen, E. Nitric Oxide Production and Signaling in Inflammation. Curr. Drug Target Inflamm. Allergy 2005, 4, 471-479. [CrossRef]

9. Salzman, A.L.; Menconi, M.J.; Unno, N.; Ezzell, R.M.; Casey, D.M.; Gonzalez, P.K.; Fink, M.P. Nitric oxide dilates tight junctions and depletes ATP in cultured Caco-2BBe intestinal epithelial monolayers. Am. J. Physio. Gastrointest. Liver Physiol. 1995, 268, G361-G373. [CrossRef] [PubMed]

10. Soufli, I.; Toumi, R.; Rafa, H.; Touil-Boukoffa, C. Overview of cytokines and nitric oxide involvement in immuno-pathogenesis of inflammatory bowel diseases. World J. Gastrointest. Pharmacol. Ther. 2016, 7, 353-360. [CrossRef] [PubMed]

11. Salim, T.; Sershen, C.L.; May, E.E. Investigating the Role of TNF- $\alpha$ and IFN- $\gamma$ Activation on the Dynamics of iNOS Gene Expression in LPS Stimulated Macrophages. PLoS ONE 2016, 11, e0153289. [CrossRef] [PubMed]

12. Vilar, A.; de Lemos, L.; Patraca, I.; Martínez, N.; Folch, J.; Junyent, F.; Verdaguer, E.; Pallàs, M.; Auladell, C.; Camins, A. Melatonin suppresses nitric oxide production in glial cultures by pro-inflammatory cytokines through p38 MAPK inhibition. Free Radic. Res. 2014, 48, 119-128. [CrossRef] [PubMed]

13. Witthöft, T.; Eckmann, L.; Kim, J.M.; Kagnoff, M.F. Enteroinvasive bacteria directly activate expression of iNOS and NO production in human colon epithelial cells. Am. J. Physiol. Gastrointest. Liver Physiol. 1998, 275, G564-G571. [CrossRef] [PubMed]

14. Salzman, A.L.; Eaves Pyles, T.; Linn, S.C.; Denenberg, A.G.; Szabó, C. Bacterial induction of inducible nitric oxide synthase in cultured human intestinal epithelial cells. Gastroenterology 1998, 114, 93-102. [CrossRef]

15. Sanongkiet, S.; Ponnikorn, S.; Udomsangpetch, R.; Tungpradabkul, S. Burkholderia pseudomallei rpoS mediates iNOS suppression in human hepatocyte (HC04) cells. FEMS Microbiol. Lett. 2016, 363, fnw161. [CrossRef]

16. Zheng, L.; Xu, Y.; Lu, J.; Liu, M.; Dai, B.; Miao, J.; Yin, Y. Variant innate immune responses of mammary epithelial cells to challenge by Staphylococcus aureus, Escherichia coli and the regulating effect of taurine on these bioprocesses. Free Radic. Biol. Med. 2016, 96, 166-180. [CrossRef] [PubMed]

17. Leppänen, T.; Tuominen, R.K.; Moilanen, E. Protein kinase $C$ and its inhibitors in the regulation of inflammation: Inducible nitric oxide synthase as an example. Basic Clin. Pharmacol. Toxicol. 2014, 114, 37-43. [CrossRef] 
18. Lakshmanan, J.; Zhang, B.; Nweze, I.C.; Du, Y.; Harbrecht, B.G. Glycogen synthase kinase 3 regulates IL-1 $\beta$ mediated iNOS expression in hepatocytes by down-regulating c-Jun. J. Cell. Biochem. 2015, 116, $133-141$. [CrossRef]

19. Peng, X.-X.; Zhang, S.-H.; Wang, X.-L.; Ye, T.-J.; Li, H.; Yan, X.-F.; Wei, L.; Wu, Z.-P.; Hu, J.; Zou, C.-P.; et al. Panax Notoginseng flower saponins (PNFS) inhibit LPS-stimulated NO overproduction and iNOS gene overexpression via the suppression of TLR4-mediated MAPK/NF-kappa B signaling pathways in RAW264.7 macrophages. Chin. Med. 2015, 10, 15. [CrossRef]

20. Bak, J.; Je, N.K.; Chung, H.Y.; Yokozawa, T.; Yoon, S.; Moon, J.-O. Oligonol Ameliorates CCl 4 -Induced Liver Injury in Rats via the NF-Kappa B and MAPK Signaling Pathways. Oxid. Med. Cell. Longev. 2016, 2016. [CrossRef]

21. Ko, H.M.; Lee, S.H.; Bang, M.; Kim, K.C.; Jeon, S.J.; Park, Y.-M.; Han, S.-H.; Kim, H.Y.; Lee, J.; Shin, C.Y. Tyrosine kinase Fyn regulates iNOS expression in LPS-stimulated astrocytes via modulation of ERK phosphorylation. Biochem. Biophys. Res. Commun. 2018, 495, 1214-1220. [CrossRef] [PubMed]

22. Kim, D.H.; Kim, M.E.; Lee, J.S. Inhibitory effects of extract from G. lanceolata on LPS-induced production of nitric oxide and IL-1 $\beta$ via down-regulation of MAPK in macrophages. Appl. Biochem. Biotechnol. 2015, 175, 657-665. [CrossRef]

23. Chen, C.C.; Wang, J.K.; Chen, W.C.; Lin, S.B. Protein kinase C eta mediates lipopolysaccharide-induced nitric-oxide synthase expression in primary astrocytes. J. Biol. Chem. 1998, 273, 19424-19430. [CrossRef]

24. Marczin, N.; Papapetropoulos, A.; Catravas, J.D. Tyrosine kinase inhibitors suppress endotoxin- and IL-1 beta-induced NO synthesis in aortic smooth muscle cells. Am. J. Physiol. Heart Circ. Physiol. 1993, 265, H1014-H1018. [CrossRef] [PubMed]

25. Bhat, N.R.; Feinstein, D.L.; Shen, Q.; Bhat, A.N. p38 MAPK-mediated Transcriptional Activation of Inducible Nitric-oxide Synthase in Glial Cells. J. Biol. Chem. 2002, 277, 29584-29592. [CrossRef] [PubMed]

26. Díaz-Guerra, M.J.; Castrillo, A.; Martín-Sanz, P.; Boscá, L. Negative regulation by protein tyrosine phosphatase of IFN-gamma-dependent expression of inducible nitric oxide synthase. J. Immunol. 1999, 162, 6776-6783. [PubMed]

27. Díaz-Guerra, M.J.; Castrillo, A.; Martín-Sanz, P.; Boscá, L. Negative regulation by phosphatidylinositol 3-kinase of inducible nitric oxide synthase expression in macrophages. J. Immunol. 1999, 162, 6184-6190.

28. Kleinert, H.; Euchenhofer, C.; Ihrig-Biedert, I.; Förstermann, U. In Murine 3T3 Fibroblasts, Different Second Messenger Pathways Resulting in the Induction of NO Synthase II (iNOS) Converge in the Activation of Transcription Factor NF-B. J. Biol. Chem. 1996, 271, 6039-6044. [CrossRef]

29. Marks-Konczalik, J.; Chu, S.C.; Moss, J. Cytokine-mediated Transcriptional Induction of the Human Inducible Nitric Oxide Synthase Gene Requires Both Activator Protein 1 and Nuclear Factor kB-binding Sites. J. Biol. Chem. 1998, 273, 22201-22208. [CrossRef]

30. Baig, M.S.; Zaichick, S.V.; Mao, M.; de Abreu, A.L.; Bakhshi, F.R.; Hart, P.C.; Saqib, U.; Deng, J.; Chatterjee, S.; Block, M.L.; et al. NOS1-derived nitric oxide promotes NF- $\mathrm{B}$ transcriptional activity through inhibition of suppressor of cytokine signaling-1. J. Exp. Med. 2015, 212, 1725-1738. [CrossRef]

31. Braverman, J.; Stanley, S.A. Nitric Oxide Modulates Macrophage Responses to Mycobacterium tuberculosis Infection through Activation of HIF-1 $\alpha$ and Repression of NF-кB. J. Immunol. 2017, 199, 1805-1816. [CrossRef] [PubMed]

32. De Vera, M.E.; Shapiro, R.A.; Nussler, A.K.; Mudgett, J.S.; Simmons, R.L.; Morris, S.M.; Billiar, T.R.; Geller, D.A. Transcriptional regulation of human inducible nitric oxide synthase (NOS2) gene by cytokines: Initial analysis of the human NOS2 promoter. Proc. Natl. Acad. Sci. USA 1996, 93, 1054-1059. [CrossRef] [PubMed]

33. Laubach, V.E.; Zhang, C.X.; Russell, S.W.; Murphy, W.J.; Sherman, P.A. Analysis of expression and promoter function of the human inducible nitric oxide synthase gene in DLD-1 cells and monkey hepatocytes. Biochim. Biophys. Acta (BBA) Gene Struct. Expr. 1997, 1351, 287-295. [CrossRef]

34. Linn, S.C.; Morelli, P.J.; Edry, I.; Cottongim, S.E.; Szabo, C.; Salzman, A.L. Transcriptional regulation of human inducible nitric oxide synthase gene in an intestinal epithelial cell line. Am. J. Physiol. Gastrointest. Liver Physiol. 1997, 272, G1499-G1508. [CrossRef] [PubMed]

35. Sharma, G.; Kar, S.; Basu Ball, W.; Ghosh, K.; Das, P.K. The curative effect of fucoidan on visceral leishmaniasis is mediated by activation of MAP kinases through specific protein kinase C isoforms. Cell. Mol. Immunol. 2014, 11, 263-274. [CrossRef] [PubMed] 
36. Pham, T.-H.; Kim, M.-S.; Le, M.-Q.; Song, Y.-S.; Bak, Y.; Ryu, H.-W.; Oh, S.-R.; Yoon, D.-Y. Fargesin exerts anti-inflammatory effects in THP-1 monocytes by suppressing PKC-dependent AP-1 and NF-kB signaling. Phytomedicine 2017, 24, 96-103. [CrossRef] [PubMed]

37. Chen, X.; Zong, C.; Gao, Y.; Cai, R.; Fang, L.; Lu, J.; Liu, F.; Qi, Y. Curcumol exhibits anti-inflammatory properties by interfering with the JNK-mediated AP-1 pathway in lipopolysaccharide-activated RAW264.7 cells. Eur. J. Pharmacol. 2014, 723, 339-345. [CrossRef]

38. Yang, C.; Yu, L.; Kong, L.; Ma, R.; Zhang, J.; Zhu, Q.; Zhu, J.; Hao, D. Pyrroloquinoline quinone (PQQ) inhibits lipopolysaccharide induced inflammation in part via downregulated NF- $\mathrm{kB}$ and p38/JNK activation in microglial and attenuates microglia activation in lipopolysaccharide treatment mice. PLOS ONE 2014, 9, e109502. [CrossRef]

39. Li, L.; Sapkota, M.; Kim, S.-W.; Soh, Y. Herbacetin inhibits inducible nitric oxide synthase via JNK and nuclear factor- $\mathrm{BB}$ in LPS-stimulated RAW264.7 cells. Eur. J. Pharmacol. 2015, 765, 115-123. [CrossRef]

40. Vodovotz, Y.; Bogdan, C.; Paik, J.; Xie, Q.W.; Nathan, C. Mechanisms of suppression of macrophage nitric oxide release by transforming growth factor beta. J. Exp. Med. 1993, 178, 605-613. [CrossRef]

41. Cabrié, A.; Guittet, O.; Tomasini, R.; Vincendeau, P.; Lepoivre, M. Crosstalk between TAp73 and TGF- $\beta$ in fibroblast regulates iNOS expression and Nrf2-dependent gene transcription. Free Radic. Biol. Med. 2019, 134, 617-629. [CrossRef] [PubMed]

42. Korhonen, R.; Lahti, A.; Hämäläinen, M.; Kankaanranta, H.; Moilanen, E. Dexamethasone inhibits inducible nitric-oxide synthase expression and nitric oxide production by destabilizing mRNA in lipopolysaccharide-treated macrophages. Mol. Pharmacol. 2002, 62, 698-704. [CrossRef] [PubMed]

43. Zhao, Y.; Shen, X.-F.; Cao, K.; Ding, J.; Kang, X.; Guan, W.-X.; Ding, Y.-T.; Liu, B.-R.; Du, J.-F. Dexamethasone-Induced Myeloid-Derived Suppressor Cells Prolong Allo Cardiac Graft Survival through iNOS- and Glucocorticoid Receptor-Dependent Mechanism. Front. Immunol. 2018, 9, 282. [CrossRef]

44. Moreira, D.R. Inhibition of Nitric Oxide Synthesis by Dexamethasone Increases Survival Rate In Plasmodium berghei-Infected Mice. bioRxiv 2018, 497966. [CrossRef]

45. Pérez-Sala, D.; Cernuda-Morollón, E.; Díaz-Cazorla, M.; Rodríguez-Pascual, F.; Lamas, S. Posttranscriptional regulation of human iNOS by the NO/cGMP pathway. Am. J. Physiol. Renal Physiol. 2001, 280, F466-F473. [CrossRef] [PubMed]

46. Zhou, X.Y.; Zhang, F.; Ying, C.J.; Chen, J.; Chen, L.; Dong, J.; Shi, Y.; Tang, M.; Hu, X.T.; Pan, Z.H.; et al. Inhibition of iNOS alleviates cognitive deficits and depression in diabetic mice through downregulating the NO/sGC/cGMP/PKG signal pathway. Behav. Brain Res. 2017, 322, 70-82. [CrossRef]

47. Geng, Y.; Lotz, M. Increased intracellular Ca2+ selectively suppresses IL-1-induced NO production by reducing iNOS mRNA stability. J. Cell Biol. 1995, 129, 1651-1657. [CrossRef]

48. Kunz, D.; Muhl, H.; Walker, G.; Pfeilschifter, J. Two distinct signaling pathways trigger the expression of inducible nitric oxide synthase in rat renal mesangial cells. Proc. Natl. Acad. Sci. USA 1994, 91, 5387-5391. [CrossRef]

49. Oddis, C.V.; Simmons, R.L.; Hattler, B.G.; Finkel, M.S. cAMP enhances inducible nitric oxide synthase mRNA stability in cardiac myocytes. Am. J. Physiol. Heart Circ. Physiol. 1995, 269, H2044-H2050. [CrossRef]

50. Linscheid, P.; Schaffner, A.; Schoedon, G. Modulation of Inducible Nitric Oxide Synthase mRNA Stability by Tetrahydrobiopterin in Vascular Smooth Muscle Cells. Biochem. Biophys. Res. Commun. 1998, 243, 137-141. [CrossRef]

51. McNeill, E.; Crabtree, M.J.; Sahgal, N.; Patel, J.; Chuaiphichai, S.; Iqbal, A.J.; Hale, A.B.; Greaves, D.R.; Channon, K.M. Regulation of iNOS function and cellular redox state by macrophage Gch1 reveals specific requirements for tetrahydrobiopterin in NRF2 activation. Free Radic. Biol. Med. 2015, 79, 206-216. [CrossRef]

52. Zheng, H.; Guo, Q.; Duan, X.; Xu, Z.; Wang, Q. l-arginine inhibited apoptosis of fish leukocytes via regulation of NF-kB-mediated inflammation, NO synthesis, and anti-oxidant capacity. Biochimie 2019, 158, 62-72. [CrossRef]

53. Yuan, C.; Zhang, X.; He, Q.; Li, J.; Lu, J.; Zou, X. L-arginine stimulates CAT-1-mediated arginine uptake and regulation of inducible nitric oxide synthase for the growth of chick intestinal epithelial cells. Mol. Cell. Biochem. 2015, 399, 229-236. [CrossRef]

54. Pahan, K.; Namboodiri, A.M.; Sheikh, F.G.; Smith, B.T.; Singh, I. Increasing cAMP attenuates induction of inducible nitric-oxide synthase in rat primary astrocytes. J. Biol. Chem. 1997, 272, 7786-7791. [CrossRef] 
55. Paul, A.; Doherty, K.; Plevin, R. Differential regulation by protein kinase C isoforms of nitric oxide synthase induction in RAW 264.7 macrophages and rat aortic smooth muscle cells. Br. J. Pharmacol. 1997, 120, 940-946. [CrossRef]

56. Chen, B.-C.; Chou, C.-F.; Lin, W.-W. Pyrimidinoceptor-mediated Potentiation of Inducible Nitric-oxide Synthase Induction in J774 Macrophages. J. Biol. Chem. 1998, 273, 29754-29763. [CrossRef]

57. Bereta, M.; Bereta, J.; Georgoff, I.; Coffman, F.D.; Cohen, S.; Cohen, M.C. Methylxanthines and Calcium-Mobilizing Agents Inhibit the Expression of Cytokine-Inducible Nitric Oxide Synthase and Vascular Cell Adhesion Molecule-1 in Murine Microvascular Endothelial Cells. Exp. Cell Res. 1994, 212, 230-242. [CrossRef]

58. Chen, B.C.; Chen, Y.H.; Lin, W.W. Involvement of p38 mitogen-activated protein kinase in lipopolysaccharide-induced iNOS and COX-2 expression in J774 macrophages. Immunology 1999, 97, 124-129. [CrossRef]

59. Kristof, A.S.; Marks-Konczalik, J.; Moss, J. Mitogen-activated protein kinases mediate activator protein-1-dependent human inducible nitric-oxide synthase promoter activation. J. Biol. Chem. 2001, 276, 8445-8452. [CrossRef]

60. Cho, M.K.; Suh, S.H.; Kim, S.G. JunB/AP-1 and NF-кB-Mediated Induction of Nitric Oxide Synthase by Bovine Type I Collagen in Serum-Stimulated Murine Macrophages. Nitric Oxide 2002, 6, 319-332. [CrossRef]

61. Guan, Z.; Baier, L.D.; Morrison, A.R. p38 Mitogen-activated Protein Kinase Down-regulates Nitric Oxide and Up-regulates Prostaglandin E 2Biosynthesis Stimulated by Interleukin-1ß. J. Biol. Chem. 1997, 272, 8083-8089. [CrossRef]

62. Zhu, F.; Du, B.; Xu, B. Anti-inflammatory effects of phytochemicals from fruits, vegetables, and food legumes: A review. Crit. Rev. Food Sci. Nutr. 2018, 58, 1260-1270. [CrossRef]

63. Olejnik, A.; Kowalska, K.; Olkowicz, M.; Juzwa, W.; Dembczynski, R.; Schmidt, M. A Gastrointestinally Digested Ribes nigrum L. Fruit Extract Inhibits Inflammatory Response in a Co-culture Model of Intestinal Caco-2 Cells and RAW264.7 Macrophages. J. Agric. Food Chem. 2016, 64, 7710-7721. [CrossRef]

64. Olejnik, A.; Kowalska, K.; Kidoń, M.; Czapski, J.; Rychlik, J.; Olkowicz, M.; Dembczyński, R. Purple carrot anthocyanins suppress lipopolysaccharide-induced inflammation in the co-culture of intestinal Caco-2 and macrophage RAW264.7 cells. Food Funct. 2016, 7, 557-564. [CrossRef]

65. Panaro, M.A.; Carofiglio, V.; Acquafredda, A.; Cavallo, P.; Cianciulli, A. Anti-inflammatory effects of resveratrol occur via inhibition of lipopolysaccharide-induced NF- KB activation in Caco-2 and SW480 human colon cancer cells. Br. J. Nutr. 2012, 108, 1623-1632. [CrossRef]

66. Phan, M.; Bucknall, M.; Arcot, J. Effect of Different Anthocyanidin Glucosides on Lutein Uptake by Caco-2 Cells, and Their Combined Activities on Anti-Oxidation and Anti-Inflammation In Vitro and Ex Vivo. Molecules 2018, 23, 2035. [CrossRef]

67. Calvello, R.; Aresta, A.; Trapani, A.; Zambonin, C.; Cianciulli, A.; Salvatore, R.; Clodoveo, M.L.; Corbo, F.; Franchini, C.; Panaro, M.A. Bovine and soybean milk bioactive compounds: Effects on inflammatory response of human intestinal Caco-2 cells. Food Chem. 2016, 210, 276-285. [CrossRef]

68. Meng, Q.; Cooney, M.; Yepuri, N.; Cooney, R.N. L-arginine attenuates Interleukin-1 $\beta$ (IL-1 $\beta$ ) induced Nuclear Factor Kappa-Beta (NF-kB) activation in Caco-2 cells. PLoS ONE 2017, 12, e0174441. [CrossRef]

69. Chen, X.-M.; Kitts, D.D. Evidence for inhibition of nitric oxide and inducible nitric oxide synthase in Caco-2 and RAW 264.7 cells by a Maillard reaction product [5-(5,6-dihydro-4H-pyridin-3-ylidenemethyl)furan-2-yl]-methanol. Mol. Cell. Biochem. 2015, 406, 205-215. [CrossRef]

70. Serra, G.; Incani, A.; Serreli, G.; Porru, L.; Melis, M.P.; Tuberoso, C.I.G.; Rossin, D.; Biasi, F.; Deiana, M. Olive oil polyphenols reduce oxysterols -induced redox imbalance and pro-inflammatory response in intestinal cells. Redox Biol. 2018, 17, 348-354. [CrossRef]

71. Serreli, G.; Melis, M.P.; Corona, G.; Deiana, M. Modulation of LPS-induced nitric oxide production in intestinal cells by hydroxytyrosol and tyrosol metabolites: Insight into the mechanism of action. Food Chem. Toxicol. 2019, 125, 520-527. [CrossRef]

72. Kim, M.S.; Kim, J.Y. Intestinal anti-inflammatory effects of cinnamon extracts in a co-culture model of intestinal epithelial Caco-2 cells and RAW264.7 macrophages. Appl. Biol. Chem. 2017, 60, 553-561. [CrossRef]

73. Groschwitz, K.R.; Hogan, S.P. Intestinal barrier function: Molecular regulation and disease pathogenesis. J. Allergy Clin. Immunol. 2009, 124, 3-20. [CrossRef]

74. Han, X.; Fink, M.P.; Delude, R.L. Proinflammatory Cytokines Cause No??-Dependent and -Independent Changes in Expression and Localization of Tight Junction Proteins in Intestinal Epithelial Cells. Shock 2003, 19, 229-237. [CrossRef] 
75. Tang, Y.; Zhang, L.; Forsyth, C.B.; Shaikh, M.; Song, S.; Keshavarzian, A. The Role of miR-212 and iNOS in Alcohol-Induced Intestinal Barrier Dysfunction and Steatohepatitis. Alcohol. Clin. Exp. Res. 2015, 39, 1632-1641. [CrossRef]

76. Menconi, M.J.; Unno, N.; Smith, M.; Aguirre, D.E.; Fink, M.P. Nitric oxide donor-induced hyperpermeability of cultured intestinal epithelial monolayers: Role of superoxide radical, hydroxyl radical, and peroxynitrite. Biochim. Biophys. Acta 1998, 1425, 189-203. [CrossRef]

77. Unno, N.; Menconi, M.J.; Smith, M.; Aguirre, D.E.; Fink, M.P. Hyperpermeability of intestinal epithelial monolayers is induced by NO: Effect of low extracellular pH. Am. J. Physiol. 1997, 272, G923-G934. [CrossRef]

78. Alican, I.; Kubes, P. A critical role for nitric oxide in intestinal barrier function and dysfunction. American J. Physiol. Gastrointest. Liver Physiol. 1996, 270, G225-G237. [CrossRef]

79. Farhadi, A. The Role of Protein Kinase C Isoforms in Modulating Injury and Repair of the Intestinal Barrier. J. Pharmacol. Exp. Ther. 2005, 316, 1-7. [CrossRef]

80. Foster, D.C.; Wedel, B.J.; Robinson, S.W.; Garbers, D.L. Mechanisms of regulation and functions of guanylyl cyclases. Rev. Physiol. Biochem. Pharmacol. 1999, 135, 1-39.

81. Kato, M.; Blanton, R.; Wang, G.-R.; Judson, T.J.; Abe, Y.; Myoishi, M.; Karas, R.H.; Mendelsohn, M.E. Direct binding and regulation of RhoA protein by cyclic GMP-dependent protein kinase I $\alpha$. J. Biol. Chem. 2012, 287, 41342-41351. [CrossRef]

82. Guillemot, L.; Citi, S. Cingulin regulates claudin-2 expression and cell proliferation through the small GTPase RhoA. Mol. Biol. Cell 2006, 17, 3569-3577. [CrossRef]

83. Rosas-Hernández, R.; Bastián, Y.; Juárez Tello, A.; Ramírez-Saíto, Á.; Escobar García, D.M.; Pozos-Guillén, A.; Mendez, J.A. Alpha-amino-3-hydroxy-5-methylisoxazole-4-propionic acid receptors modulate the reorganization of F-actin in Bergmann glia cells through the activation of RhoA. J. Neurochem. 2018, 112, 97. [CrossRef]

84. Sedzinski, J.; Hannezo, E.; Tu, F.; Biro, M.; Wallingford, J.B. RhoA regulates actin network dynamics during apical surface emergence in multiciliated epithelial cells. J. Cell. Sci. 2017, 130, 420-428. [CrossRef]

85. Stadtman, E.R. Protein Oxidation in Aging and Age-Related Diseases. Ann. N. Y. Acad. Sci. 2006, 928, $22-38$. [CrossRef]

86. Kim, B.; Breton, S. The MAPK/ERK-Signaling Pathway Regulates the Expression and Distribution of Tight Junction Proteins in the Mouse Proximal Epididymis. Biol. Reprod. 2016, 94, 22. [CrossRef]

87. Lander, H.M.; Hajjar, D.P.; Hempstead, B.L.; Mirza, U.A.; Chait, B.T.; Campbell, S.; Quilliam, L.A. A Molecular Redox Switch on p21 ras. J. Biol. Chem. 1997, 272, 4323-4326. [CrossRef]

88. Ma, T.Y.; Iwamoto, G.K.; Hoa, N.T.; Akotia, V.; Pedram, A.; Boivin, M.A.; Said, H.M. TNF-alpha-induced increase in intestinal epithelial tight junction permeability requires NF-kappa B activation. Am. J. Physiol. Gastrointest. Liver Physiol. 2004, 286, G367-G376. [CrossRef]

89. Tang, Y.; Clayburgh, D.R.; Mittal, N.; Goretsky, T.; Dirisina, R.; Zhang, Z.; Kron, M.; Ivancic, D.; Katzman, R.B.; Grimm, G.; et al. Epithelial NF-kappaB enhances transmucosal fluid movement by altering tight junction protein composition after T cell activation. Am. J. Pathol. 2010, 176, 158-167. [CrossRef]

90. Choi, H.J.; Kim, J.; Park, S.-H.; Do, K.H.; Yang, H.; Moon, Y. Pro-inflammatory NF-kB and early growth response gene 1 regulate epithelial barrier disruption by food additive carrageenan in human intestinal epithelial cells. Toxicol. Lett. 2012, 211, 289-295. [CrossRef]

91. Yang, S.; Yu, M.; Sun, L.; Xiao, W.; Yang, X.; Sun, L.; Zhang, C.; Ma, Y.; Yang, H.; Liu, Y.; et al. Interferon- $\gamma$-induced intestinal epithelial barrier dysfunction by NF-кB/HIF-1 $\alpha$ pathway. J. Interferon Cytokine Res. 2014, 34, 195-203. [CrossRef]

92. Jeong, C.H.; Seok, J.S.; Petriello, M.C.; Han, S.G. Arsenic downregulates tight junction claudin proteins through p38 and NF-KB in intestinal epithelial cell line, HT-29. Toxicology 2017, 379, 31-39. [CrossRef]

93. Wu, P.; Jiang, W.-D.; Jiang, J.; Zhao, J.; Liu, Y.; Zhang, Y.-A.; Zhou, X.-Q.; Feng, L. Dietary choline deficiency and excess induced intestinal inflammation and alteration of intestinal tight junction protein transcription potentially by modulating NF- $\mathrm{B}$, STAT and p38 MAPK signaling molecules in juvenile Jian carp. Fish Shellfish Immunol. 2016, 58, 462-473. [CrossRef]

94. Wu, M.; Bian, Q.; Liu, Y.; Fernandes, A.; Taylor, A.; Pereira, P.; Shang, F. Sustained oxidative stress inhibits NF- $\mathrm{BB}$ activation partially via inactivating the proteasome. Free Radic. Biol. Med. 2009, 46, 62-69. [CrossRef]

95. Matthews, J.R.; Botting, C.H.; Panico, M.; Morris, H.R.; Hay, R.T. Inhibition of NF- B DNA Binding by Nitric Oxide. Nucleic Acids Res. 1996, 24, 2236-2242. [CrossRef] 
96. Liang, N.; Kitts, D.D. Amelioration of oxidative stress in Caco-2 cells treated with pro-inflammatory proteins by chlorogenic acid isomers via activation of the Nrf2-Keap1 signaling pathway. J. Agric. Food Chem. 2018, 66, 11008-11017. [CrossRef]

97. Brennan, M.-L.; Wu, W.; Fu, X.; Shen, Z.; Song, W.; Frost, H.; Vadseth, C.; Narine, L.; Lenkiewicz, E.; Borchers, M.T.; et al. A tale of two controversies: Defining both the role of peroxidases in nitrotyrosine formation in vivo using eosinophil peroxidase and myeloperoxidase-deficient mice, and the nature of peroxidase-generated reactive nitrogen species. J. Biol. Chem. 2002, 277, 17415-17427. [CrossRef]

98. Van der Vliet, A.; Eiserich, J.P.; Halliwell, B.; Cross, C.E. Formation of reactive nitrogen species during peroxidase-catalyzed oxidation of nitrite. A potential additional mechanism of nitric oxide-dependent toxicity. J. Biol. Chem. 1997, 272, 7617-7625. [CrossRef]

99. Wu, W.; Chen, Y.; Hazen, S.L. Eosinophil peroxidase nitrates protein tyrosyl residues. Implications for oxidative damage by nitrating intermediates in eosinophilic inflammatory disorders. J. Biol. Chem. 1999, 274, 25933-25944. [CrossRef]

100. Schafer, F.Q.; Buettner, G.R. Redox environment of the cell as viewed through the redox state of the glutathione disulfide/glutathione couple. Free Radic. Biol. Med. 2001, 30, 1191-1212. [CrossRef]

101. Cotgreave, I.A.; Gerdes, R.G. Recent Trends in Glutathione Biochemistry-Glutathione-Protein Interactions: A Molecular Link between Oxidative Stress and Cell Proliferation? Biochem. Biophys. Res. Commun. 1998, 242, 1-9. [CrossRef]

102. Herrlich, P.; Böhmer, F.D. Redox regulation of signal transduction in mammalian cells. Biochem. Pharmacol. 2000, 59, 35-41. [CrossRef]

103. Rao, R.K.; Li, L.; Baker, R.D.; Baker, S.S.; Gupta, A. Glutathione oxidation and PTPase inhibition by hydrogen peroxide in Caco-2 cell monolayer. Am. J. Physiol. Gastrointest. Liver Physiol. 2000, 279, G332-G340. [CrossRef]

104. Sun, J.; Steenbergen, C.; Murphy, E. S-Nitrosylation: NO-Related Redox Signaling to Protect Against Oxidative Stress. Antioxid. Redox Signal. 2006, 8, 1693-1705. [CrossRef]

105. Yamamoto, S.; Suzuki, H.; Ueda, N.; Takahashi, Y.; Yoshimoto, T. Mammalian Lipoxygenases. In The Eicosanoids; John Wiley \& Sons, Ltd.: Chichester, UK, 2004; pp. 53-59.

106. Spiteller, G. Peroxyl Radicals Are Essential Reagents in the Oxidation Steps of the Maillard Reaction Leading to Generation of Advanced Glycation End Products. Ann. N. Y. Acad. Sci. 2008, 1126, 128-133. [CrossRef]

107. Zamora, R.; Hidalgo, F.J. Coordinate Contribution of Lipid Oxidation and Maillard Reaction to the Nonenzymatic Food Browning. Crit. Rev. Food Sci. Nutr. 2005, 45, 49-59. [CrossRef]

108. Carlsen, C.U.; Møller, J.K.S.; Skibsted, L.H. Heme-iron in lipid oxidation. Coord. Chem. Rev. 2005, $249,485-498$. [CrossRef]

109. Gebicki, S.; Gebicki, J.M. Formation of peroxides in amino acids and proteins exposed to oxygen free radicals. Biochem. J. 1993, 289, 743-749. [CrossRef]

110. Neužil, J.; Gebicki, J.M.; Stocker, R. Radical-induced chain oxidation of proteins and its inhibition by chain-breaking antioxidants. Biochem. J. 1993, 293, 601-606. [CrossRef]

111. Forsmark-AndrÉe, P.; Dallner, G.; Ernster, L. Endogenous ubiquinol prevents protein modification accompanying lipid peroxidation in beef heart submitochondrial particles. Free Radic. Biol. Med. 1995, 19, 749-757. [CrossRef]

112. Gardner, H.W. Lipid hydroperoxide reactivity with proteins and amino acids: A review. J. Agric. Food Chem. 1979, 27, 220-229. [CrossRef]

113. Schaich, K.M.; Karel, M. Free radical reactions of peroxidizing lipids with amino acids and proteins: An ESR study. Lipids 1976, 11, 392-400. [CrossRef]

114. Davies, M.J. Protein oxidation and peroxidation. Biochem. J. 2016, 473, 805-825. [CrossRef]

115. Roubal, W.T.; Tappel, A.L. Damage to proteins, enzymes, and amino acids by peroxidizing lipids. Arch. Biochem. Biophys. 1966, 113, 5-8. [CrossRef]

116. Götz, M.E.; Gerlach, M. Formation of Radicals. In Brain Damage and Repair; Springer: Dordrecht, The Netherlands, 2004; Volume 8, pp. 135-164.

117. Marnett, L.J. Oxyradicals and DNA damage. Carcinogenesis 2000, 21, 361-370. [CrossRef]

118. Hogg, N.; Parthasarthy, S.; Kalyanaraman, B. Inhibition of low-density lipoprotein oxidation by nitric oxide. Free Radic. Biol. Med. 1993, 15, 495. [CrossRef] 
119. Rubbo, H.; Radi, R.; Trujillo, M.; Telleri, R.; Kalyanaraman, B.; Barnes, S.; Kirk, M.; Freeman, B.A. Nitric oxide regulation of superoxide and peroxynitrite-dependent lipid peroxidation. Formation of novel nitrogen-containing oxidized lipid derivatives. J. Biol. Chem. 1994, 269, 26066-26075.

120. Rubbo, H.; Parthasarathy, S.; Barnes, S.; Kirk, M.; Kalyanaraman, B.; Freeman, B.A. Nitric oxide inhibition of lipoxygenase-dependent liposome and low-density lipoprotein oxidation: Termination of radical chain propagation reactions and formation of nitrogen-containing oxidized lipid derivatives. Arch. Biochem. Biophys. 1995, 324, 15-25. [CrossRef]

121. Hayashi, K.; Noguchi, N.; Niki, E. Action of nitric oxide as an antioxidant against oxidation of soybean phosphatidylcholine liposomal membranes. FEBS Lett. 1995, 370, 37-40. [CrossRef]

122. Goss, S.P.; Hogg, N.; Kalyanaraman, B. The antioxidant effect of spermine NONOate in human low-density lipoprotein. Chem. Res. Toxicol. 1995, 8, 800-806. [CrossRef]

123. Goss, S.P.; Hogg, N.; Kalyanaraman, B. The effect of nitric oxide release rates on the oxidation of human low density lipoprotein. J. Biol. Chem. 1997, 272, 21647-21653. [CrossRef] [PubMed]

124. Darley-usmar, V.M.; Hogg, N.; O'leary, V.J.; Wilson, M.T.; Moncada, S. The Simultaneous Generation of Superoxide and Nitric Oxide Can Initiate Lipid Peroxidation in Human Low Density Lipoprotein. Free Radic. Res. Commun. 2009, 17, 9-20. [CrossRef]

125. Kanner, J.; Harel, S.; Granit, R. Nitric oxide, an inhibitor of lipid oxidation by lipoxygenase, cyclooxygenase and hemoglobin. Lipids 1992, 27, 46-49. [CrossRef] [PubMed]

126. Beckman, J.S. Oxidative Damage and Tyrosine Nitration from Peroxynitrite. Chem. Res. Toxicol. 1996, 9, 836-844. [CrossRef] [PubMed]

127. Iravani, M.M.; Kashefi, K.; Mander, P.; Rose, S.; Jenner, P. Involvement of inducible nitric oxide synthase in inflammation-induced dopaminergic neurodegeneration. Neuroscience 2002, 110, 49-58. [CrossRef]

128. Radi, R.; Beckman, J.S.; Bush, K.M.; Freeman, B.A. Peroxynitrite-induced membrane lipid peroxidation: The cytotoxic potential of superoxide and nitric oxide. Arch. Biochem. Biophys. 1991, 288, 481-487. [CrossRef]

129. Gow, A.J.; Ischiropoulos, H. Nitric oxide chemistry and cellular signaling. J. Cell. Physiol. 2001, 187, $277-282$. [CrossRef] [PubMed] 